\title{
The ecological value of long-term studies of birds and mammals in Central America, South America and Antarctica
}

\author{
Megan Taig-Johnston ${ }^{1}$, Madeline K. Strom¹', Kendall Calhoun², Kendra Nowak ${ }^{3}$, Luis A. Ebensperger ${ }^{4}$ \\ and Loren Hayes ${ }^{1 *}$
}

\begin{abstract}
This review covers long-term ecological studies in Central America, South America, and Antarctica that include at least 10 years of data on both terrestrial and marine mammals as well as birds. Specifically, we compiled long-term research on social systems, population ecology, and community ecology. Long-term research is necessary to understand decadal trends and dynamics that would otherwise go unnoticed in short-term studies. This review highlights the impact of ecological conditions as well as territoriality and conflict on social organization and structure, the role that environmental perturbations and climate change have on populations, and how interaction between biotic and abiotic factors influence entire ecological communities. It especially highlights the need for additional long-term studies to assess climate change trends and the ecological changes that will follow.
\end{abstract}

Keywords: Long-term studies, Social systems, Population ecology studies, Community ecology studies, ENSO, Small mammals

\section{Background}

Increasingly, greater value is placed in long-term ecological studies [1-6]. Long-term studies have generated important insights into ecological processes at the population $[7,8]$, community [9-11], and ecosystem [12] scales and have been applied to urban systems [13]. Long-term studies have informed theory on impact of environmental change or perturbations to these processes ([7, 14-17]). Continuously collected datasets over appropriate temporal scales are required to answer specific ecological and evolutionary questions $[1,2]$. For example, long-term ecological studies have shown how complex phenomena such as El Niño-Southern Oscillation (ENSO) events influence organisms at multiple scales (individual to ecosystem; [18]). Data from a longterm study of North American marmots revealed the potentially evolutionary implications of environmental change on high altitude organisms $[7,19]$. Not surprisingly, patterns revealed in some long-term studies differ from those in short-term field studies resulting in challenges to existing

\footnotetext{
*Correspondence: Ioren-hayes@utc.edu; octodon1@yahoo.com ${ }^{1}$ Department of Biology, Geology, and Environmental Science, University of Tennessee at Chattanooga, 615 McCallie Ave, Chattanooga, TN 37405, USA Full list of author information is available at the end of the article
}

paradigms [14]. Thus, it is now clear that long-term datasets are essential in the development of predictive models and evidence-based management strategies $[4,20]$.

Recent syntheses of long-term studies of animals have focused largely on studies conducted in Africa, Australia, North America, and Europe [2, 21]. Long-term studies have also been an integral part of ecological research in central and South America and Antarctica ([1]; Figs. 1 and 2; Tables 1 and 2). Perhaps, the most well-known long-term study in the region is Rosemary and Peter Grant's study of evolutionary change in Galapagos finches [22, 23]. The Grants' study, 40 years in the making, has shed important insights into factors shaping phenotypic change and served as a model for long-term ecological research. Other longterm studies, including decades of research conducted at three Long-Term Socio-ecological Research (LTSER) sites in Chile - Parque Nacional Bosque Fray Jorge [24], Senda Darwin Biological Station [25] and Omora Ethnobotanical Park [26] - have contributed to theory and motivated efforts to integrate scientific and social science approaches to tackle large-scale environmental challenges [1, 27, 28]. There have also been numerous 'lower profile', but valuable long-term studies in the region (see Table 1 


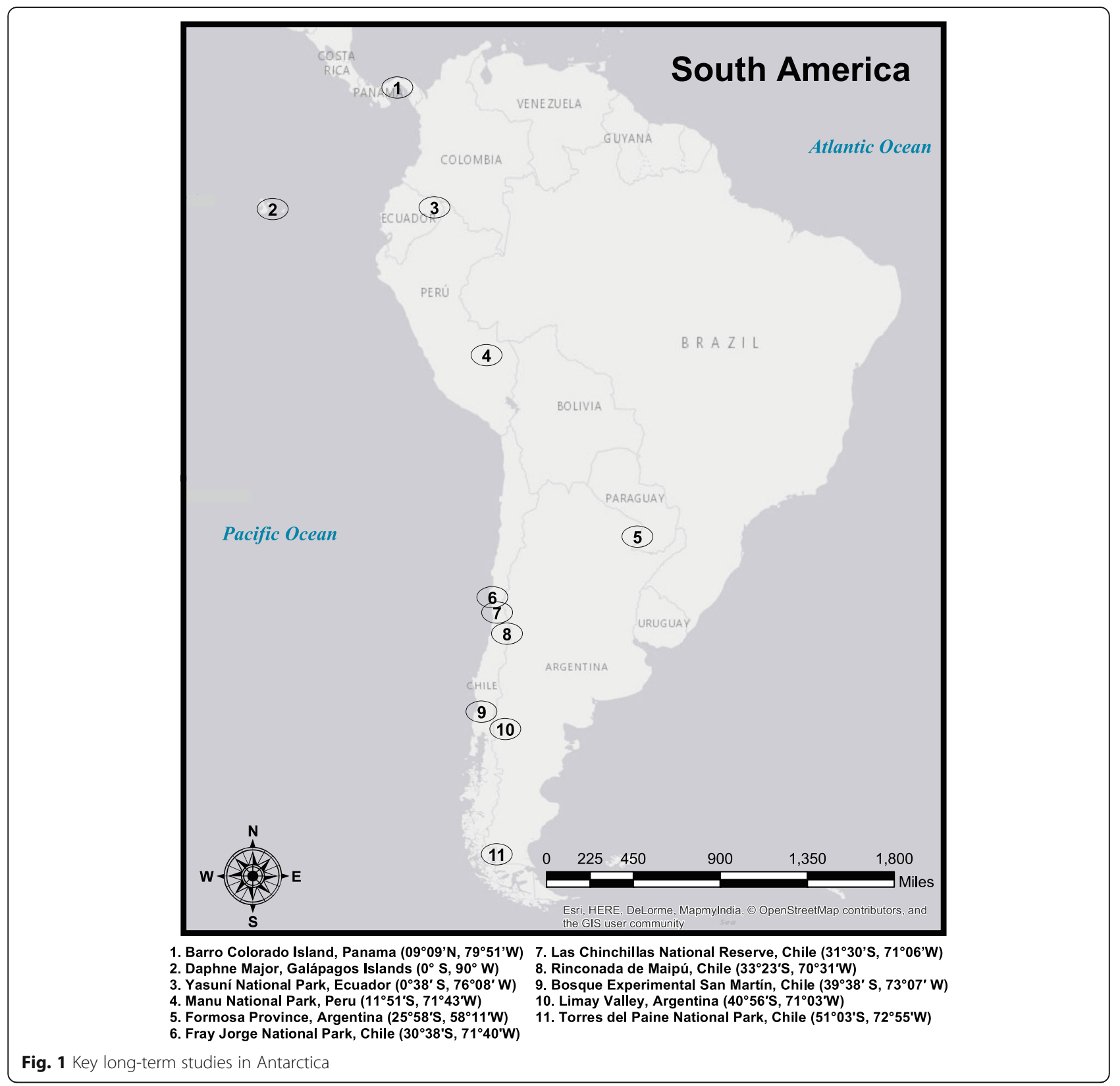

in $[1,29,30])$. Together, these studies have answered questions about ecological and socioecological processes in semi-arid and arid shrublands, forests (oldgrowth mixed and evergreen, tropical forests, subAntarctic), grasslands (steppe), rocky intertidal, estuarine, and oceanic ecosystems [1]. Thus, there is great potential to learn broad, important concepts from this work and promote the continuation of long-term data collection in these regions.

Our objective is to highlight major advances in our understanding of ecology that have emerged from longterm studies of birds and mammals in Central and South America and Antarctica. Our review will provide the basis of comparison to long-term studies of birds and mammals in other regions of the world and inform theory regarding the impact of decadal ecological changes and/or climate change on animal behavior as well as population and community processes. We define a long-term study as one that covers 10 or more continuous years of study. We identified long-term studies from papers that reported datasets of 10 or more years as well as series of short-term studies that make up a long-term study. We include studies in which individuals are individually marked as well as long-term monitoring studies in which individuals are not marked. A comprehensive review of all long-term studies in the 


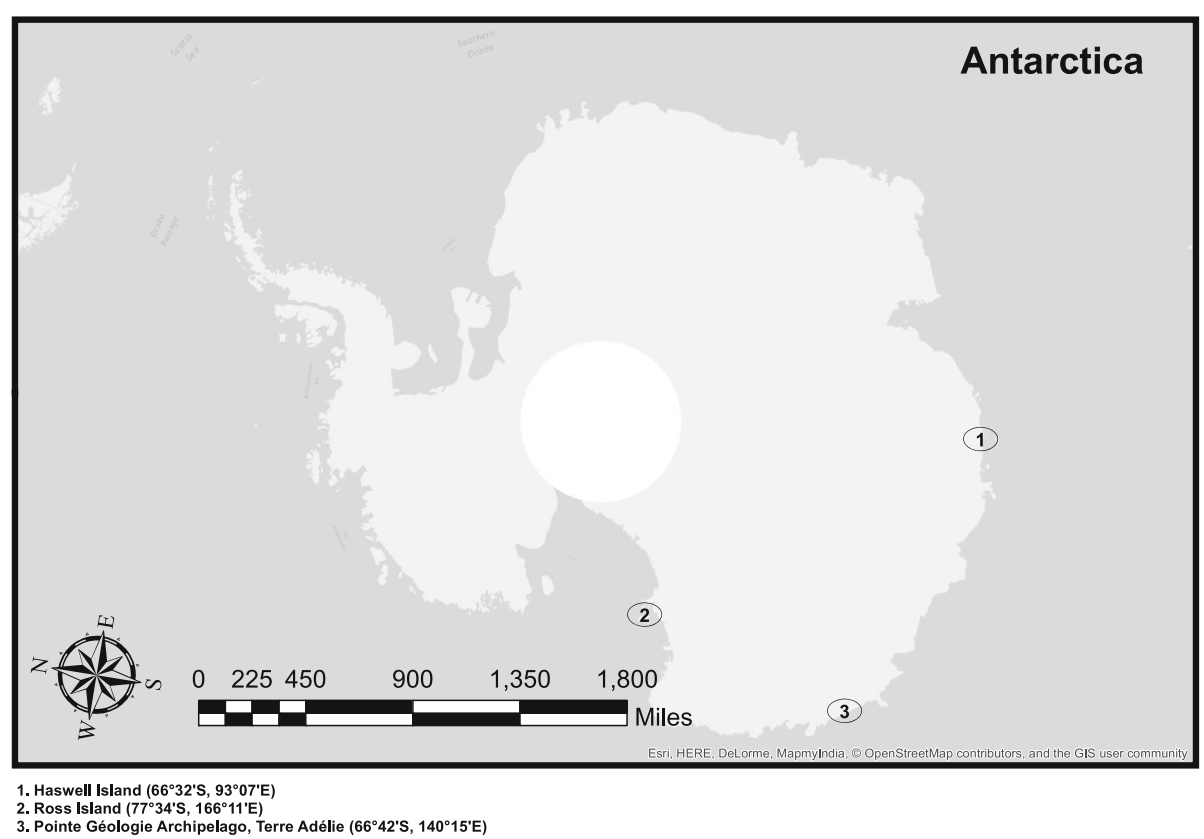

Fig. 2 Key long-term studies in South America

region, including plant-based population studies, is beyond the scope of this review. Rather, we aim to highlight three significant, ecological themes to which long-term field studies of birds and mammals in the region - including marine environments and Antarctica - have made significant contributions: (i) social systems, (ii) animal population and evolutionary ecology, and (iii) community ecology.

\section{Social ecology}

Long-term studies on social systems allow us to analyze trends across generations as opposed to extrapolating data based on single-generation studies. The following studies cover factors including resource availability and other ecological conditions and their influence on mating system formation, social organization, and reproductive success from a long-term perspective.

Since 2003, the 'Comparative Socioecology of Monogamous Primates' study in Yasuní National Park and Biosphere Reserve in eastern Ecuador (76 $08^{\prime}$ W, $0^{\circ} 38^{\prime}$ S) and Formosa Province, Argentina (58 $\left.11^{\prime} \mathrm{W}, 25^{\circ} 58^{\prime} \mathrm{S}\right)$ has revealed insights into ecological and social factors influencing social monogamy in primate species including owl monkeys (Aotus azarai), red titi monkeys (Callicebus discolor), and equatorial sakis (Pithecia aequatorialis) [31-33]. One theme that has emerged from this work is that intrasexual conflict plays an important role in social dynamics and reproductive success in some species but not others. In a study of 18 owl monkey groups in Argentina, [31] observed that individuals who mate with a single opposite-sex individual produced
$25 \%$ more offspring per decade of tenure than individuals mating with multiple partners (both males and females). It was also shown that male intruders initiated the splitting up of male-female pairs and in some cases resulted in the death of expelled individuals, observations consistent with strong intra-sexual conflict in this species. In contrast, a focal study of one equatorial saki group and one red titi monkey group in Yasuní National Park suggests that intrasexual conflict is low and groups vary in social composition [32, 34]. Monkey groups are continually being tracked (e.g. [34]), which ultimately should provide greater power to place inferences about the importance of social monogamy in South American primates.

Giant otter (Pteronura brasiliensis) social units consist of one dominant breeding pair and their subordinate offspring (non-breeding helper adults and juveniles/infants) until males reach sexual maturity and disperse [35]. Whereas some females disperse, others remain philopatric to their natal group and ultimately, take their mother's or sister's reproductive position in the group. A long-term study (1991-2006) of these otters in Manu

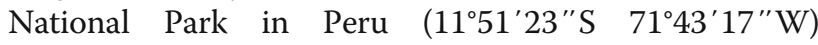
revealed that groups were larger and the number of offspring produced by females was greater in territories with more access to lakes, presumably due to greater availability of fish [36]. Lower quality territories in terms of size (and associated fish abundance) supported only monogamous pairs. Intriguingly, variation in group size did not predict variation in the number of offspring produced by females regardless of territorial quality and 
Table 1 Long-term studies of social systems and population ecology in central and South America and Antarctica

\begin{tabular}{|c|c|c|c|c|c|c|}
\hline Genus and species & Common name & Location of study & $\begin{array}{l}\text { Duration of } \\
\text { study (years) }\end{array}$ & $\begin{array}{l}\text { Individually } \\
\text { marked? }\end{array}$ & Theme & Key reference \\
\hline Octodon degus & Degu & $\begin{array}{l}\text { North-central } \\
\text { Chile }\end{array}$ & $\begin{array}{l}12 \text { years } \\
(2004-2016)\end{array}$ & $\mathrm{Y}$ & Social systems & [29] \\
\hline Oligoryzomys longicaudatus & Long-tailed rice rat & Chile, rainforest & $\begin{array}{l}19 \text { years } \\
(1979-1998)\end{array}$ & Y & Social systems & [65] \\
\hline Lama guanicoe & Guanaco & Chilean Patagonia & $\begin{array}{l}10 \text { years } \\
(1989-1999)\end{array}$ & Y & Social systems & {$[40]$} \\
\hline Pithecia aequatorialis & Equatorial sakis & Ecuador & $\begin{array}{l}10 \text { years } \\
(2004-2014)\end{array}$ & Y & Social systems & {$[32]$} \\
\hline Pteronura brasiliensis & Giant otter & Peru & $\begin{array}{l}15 \text { years } \\
(1991-2006)\end{array}$ & Y & Social systems & {$[36]$} \\
\hline Ctenomys sociabilis & Colonial tuco-tuco & Argentina & $\begin{array}{l}20 \text { years } \\
(1994-2004)\end{array}$ & Y & Social systems & {$[45]$} \\
\hline Aptenodytes forsteri & Emperor penguin & Antarctica & $\begin{array}{l}54 \text { years } \\
(1957-2010\end{array}$ & N & $\begin{array}{l}\text { Population and } \\
\text { evolutionary ecology }\end{array}$ & {$[80]$} \\
\hline Spheniscus magellanicus & Magellanic penguin & $\begin{array}{l}\text { Punta Tumbo, } \\
\text { Argentina }\end{array}$ & $\begin{array}{l}28 \text { years } \\
(1982-2010)\end{array}$ & Y & $\begin{array}{l}\text { Population and } \\
\text { evolutionary ecology }\end{array}$ & {$[75]$} \\
\hline Apenodytes forsteri & Emperor penguin & $\begin{array}{l}\text { Point Geologie, } \\
\text { Antarctica }\end{array}$ & $\begin{array}{l}46 \text { years } \\
(1956-2001)\end{array}$ & N & $\begin{array}{l}\text { Population and } \\
\text { evolutionary ecology }\end{array}$ & {$[84]$} \\
\hline Pagodroma nivea & Snow petrel & $\begin{array}{l}\text { Point Geologie, } \\
\text { Antarctica }\end{array}$ & $\begin{array}{l}40 \text { years } \\
(1963-2002)\end{array}$ & $\mathrm{N}$ & $\begin{array}{l}\text { Population and } \\
\text { evolutionary ecology }\end{array}$ & [71] \\
\hline Fulmar glacialoides & Southern fulmar & $\begin{array}{l}\text { Point Geologie, } \\
\text { Antarctica }\end{array}$ & $\begin{array}{l}40 \text { years } \\
(1963-2002)\end{array}$ & N & $\begin{array}{l}\text { Population and } \\
\text { evolutionary ecology }\end{array}$ & [71] \\
\hline Pygoscelis adelae & Adelie penguin & Ross Island & $\begin{array}{l}41 \text { years } \\
(1960-2000)\end{array}$ & N & $\begin{array}{l}\text { Population and } \\
\text { evolutionary ecology }\end{array}$ & [84] \\
\hline Cephalorhynchus eutropia & Chilean dolphin & Chile & $\begin{array}{l}14 \text { years } \\
(1988-2012)\end{array}$ & Y & $\begin{array}{l}\text { Population and } \\
\text { evolutionary ecology }\end{array}$ & {$[68]$} \\
\hline Phyllotis darwini & Darwin's leaf-eared mouse & Chile, Auco & $\begin{array}{l}10 \text { years } \\
(1987-1996)\end{array}$ & Y & $\begin{array}{l}\text { Population and } \\
\text { evolutionary ecology }\end{array}$ & [115] \\
\hline $40+$ marine species & See $[88]$ & $\begin{array}{l}\text { East coast of } \\
\text { South America }\end{array}$ & $\begin{array}{l}38 \text { years } \\
(1976-2013)\end{array}$ & Y & $\begin{array}{l}\text { Population and } \\
\text { evolutionary ecology }\end{array}$ & {$[85]$} \\
\hline $\begin{array}{l}\text { Phyllostomidae bats } \\
\text { (30 species) }\end{array}$ & See [33] & $\begin{array}{l}\text { Barro Colorado } \\
\text { Island, Panama }\end{array}$ & $\begin{array}{l}10 \text { years } \\
(1975-1985)\end{array}$ & $\mathrm{N}$ & $\begin{array}{l}\text { Population and } \\
\text { evolutionary ecology }\end{array}$ & [114] \\
\hline $\begin{array}{l}\text { Geospiza fortis, Geospiza } \\
\text { scandens Geospiza fuliginosa }\end{array}$ & $\begin{array}{l}\text { Médium ground finch, common } \\
\text { cactus finch, small ground finch }\end{array}$ & $\begin{array}{l}\text { Daphne Major, } \\
\text { Galapagos Islands }\end{array}$ & $\begin{array}{l}30 \text { years } \\
(1972-2001)\end{array}$ & Y & $\begin{array}{l}\text { Population and } \\
\text { evolutionary ecology }\end{array}$ & {$[22]$} \\
\hline
\end{tabular}

size. These observations suggest competition is relaxed and sociality is favored when resource availability is high [37], but that the benefits of living in groups are limited, and that cooperative breeding may be favored when resources are patchy [36].

During the breeding season, male guanacos (Lama guanacoe) are found either in family groups, in maleonly groups consisting of non-territorial males, or as solo territorial males [38]. Guanacos exhibit seasonal resource-defense polygyny in which males compete for access to resources required by females in order to ensure reproductive success [39]. Using a 10-year dataset of individually marked guanacos in a population in Parque Nacional Torres del Paine $\left(51^{\circ} 03^{\prime} \mathrm{S}, 72^{\circ} 55^{\prime} \mathrm{W}\right)$, [40] determined that male reproductive success is heavily influenced by male territoriality and social structure. Most

Table 2 Long-term studies of community ecology in central and South America and Antarctica

\begin{tabular}{|c|c|c|c|c|c|}
\hline Community & Species & Location of study & $\begin{array}{l}\text { Duration of study } \\
\text { (years) }\end{array}$ & Individually marked? & Key Reference \\
\hline Rolling pampas, agricultural lands & 7 species & Argentina & 24 years $(1984-2008)$ & $\mathrm{Y}$ & {$[87]$} \\
\hline Semi-arid rodent community & $7+$ species & $\begin{array}{l}\text { Bosque Nacional Parque } \\
\text { Fray Jorge, Chile }\end{array}$ & 26 years (1989-present) & Y & [9] \\
\hline Predator assemblage & $6+$ species & Auco. Chile & 28 years (1987-present) & $\mathrm{N}$ & [104] \\
\hline
\end{tabular}


breeding and non-breeding males show strong sitefidelity throughout the mating season and between years. For breeding (family group) territorial males, previous familiarity with a given area seems to improve mating success $[41,42]$, and the probability that individuals reproduce multiple times over a lifetime in previously held territories influences site fidelity. Despite their low probability of mating, solo territorial males may exhibit site fidelity due to the difficulties of establishing territories in an unfamiliar location, and because of the uncertainty of siring offspring. Females move freely between male territories, often in the post-mating season [43], implying a polygynous mating system based on territory defense. Solo territorial males exhibit site-fidelity near territorial males and mate with females that become reproductively active late in the season. High site fidelity might indicate that there are factors other than resource availability, such as aggression, social status, and physical condition [44] that may influence guanaco mating system.

One of the most comprehensive long-term studies in South America has been Eileen Lacey's 20-year study of the social system of the colonial tuco-tuco (Ctenomys sociabilis), a subterranean rodent found in the Limay Valley of Argentina ( $40^{\circ} 56^{\prime} \mathrm{S}, 71^{\circ} 03^{\prime} \mathrm{W}$ ) (Fig. 2). Female colonial tuco-tucos in this population share burrows with 1-4 generations of closely related females and a single immigrant male $[45,46]$. Groups do not switch burrow systems between consecutive years [46], suggesting that the costs of burrow-switching are high. Similar to the subterranean bathyergid mole rats of Africa (Heterocephalus glaber) [47], [48] hypothesized that group living in ctenomyid rodents is associated with hard soils and patchily distributed resources. Contrary to the expectations of the aridity-food distribution hypothesis [47], solitary Patagonian tuco-tucos (C. haigi) in the Limay Valley live in areas with harder soils than do colonial tuco-tucos [48]. Tammone et al. [49] found that across their full geographic range, colonial tuco-tucos occur in habitats characterized by dry soil as well as wet soil, indicating that habitat specialization may not be as important as previously thought. However, spatial scaledependent patchiness of favorable habitat may still influence dispersal in the species.

Contrary to expectations, group living results in direct fitness costs to colonial tuco-tuco females. Philopatric yearling females rear fewer offspring per capita than dispersing females and annual reproductive success of group living females is $26-40 \%$ less than expected [30]. Lifetime reproductive success and survival to a second breeding year did not differ between social strategies (disperser vs. philopatric) leading [30] to argue that ecological constraints on dispersal explains group living in colonial tuco-tucos. Although the amount of time that adults attend a communal nest increased with the number of adults in the group
[50], per capita direct fitness decreased with increasing adult group size [30], suggesting that group size benefits or benefits of communal care are minimal and/or do not exceed potential costs of living in groups.

A 12-year study (2005-present) led by Luis Ebensperger and Loren Hayes on the common degu (Octodon degus), a semi-fossorial rodent endemic to Chile, has generated valuable insight into ecological and social conditions influencing direct fitness consequences of group living. In contrast to colonial tuco-tucos, the availability of critical resources i.e., burrows for rearing offspring, does not have a strong influence on degu sociality [51]. Groups form as a result of philopatry and the movement of adults between social units [52], resulting in groups that lack strong kin structure [53, 54]. Initial short-term studies of 2-3 years suggested that group living resulted in direct fitness costs to females [51, 55], an extreme cost given that degus are ecologically semelparous [56]. However, analyses of an 8-year dataset suggested that the relationship between per capita direct fitness and group size is positive under conditions of low mean food but not conditions of high mean food [29]. Direct fitness of adult group members is also influenced by stability in group composition in sex-specific ways. Whereas male degus benefit the most from low female group membership stability, females benefit the most from high female group membership stability [57]. Interestingly, these findings suggest a potential sex conflict over stability of social groups. Most recently, direct fitness variation among females within multi-female groups was noted to decrease with increasing relatedness of females in groups and increasing soil hardness at burrow systems (Hayes et al. submitted). Together, these observations suggest that benefits of cooperation among females are modulated by ecological and social conditions. In particular, benefits based on mean reproductive success materialize under harsh ecological conditions and high social stability. On the other hand, benefits in terms of decreasing variance in reproductive success materialize mostly in kin groups exposed to harsh soil conditions (Hayes, LD and Ebensperger LA, unpublished data).

\section{Population and evolutionary ecology}

Populations undergo natural fluctuations due to various factors, including climate fluctuations that ca be traced in long-term studies and their influence can vary from year to year. Long-term studies can track changes in density, composition, mortality, and distributions as well as potential causes, such as climate change and density-dependent effects. The following studies examine these factors in both terrestrial and marine mammals and birds.

From 1972 to 2001, Peter and Rosemary Grant have examined morphological variance (body size and beak 
size and shape) and ecology of the medium ground finch (Geospiza fortis) and the cactus finch (Geospiza scandens) on Daphne Major, Galapagos $\left(0^{\circ} 25^{\prime} \mathrm{N},-90^{\circ} 22^{\prime}\right.$ W) [22]. They were able to study natural selection and introgressive hybridization in these two species. Mean body size and beak shape were significantly different in the two species from the beginning of the study to the end. However, the two species differed on the direction of selection for net body and beak size. Natural selection on these traits led to evolution in these species due to the high heritability of these traits. There was occasional hybridization between the two study species as well as a third, the small ground finch (Geospiza fuliginosa), leading to additive genetic variation related to beak size and shape and body size traits. The Grants also examined the effect of an El Niño event on food availability for the finches, which led to selection for smaller beak sizes [58]. Over the decades of studying these finches, the Grants determined that the morphological evolution that took place could not have been predicted at the beginning of the study, highlighting the importance of longterm studies on understanding evolutionary trends and the effects of extreme weather events.

Ronald Sarno and colleagues' study of guanacos (L. guanaco) in Torres del Paine National Park ( $51^{\circ} 3^{\prime} \mathrm{S}, 72^{\circ} 55^{\prime}$ W), Chile has revealed insights in demographic processes influencing population growth. Sarno and Franklin [59] found mean yearly birth mass (a predictor of reproductive success) was negatively associated with population density. Maternal condition can suffer under higher densities, which in turn impacts birth mass $[60,61]$ and survival [62]. Predation by Patagonian pumas (Puma concolor) and winter snowfall are additional predictors of offspring survival in this population $([62,63])$. Population density is an important predictor of population growth rate in a second population on Tierra del Fuego island, Chile $\left(53^{\circ} 9^{\prime}\right.$ S, $69^{\circ} 3^{\prime}$ $\mathrm{W})$, that has been the focus of a long-term study. Between 1977 and 2012, there was a negative relationship between the population growth rate and abundance of guanacos [64]. The number of sheep in the study site, annual mean precipitation, and winter mean temperature do not seem to be predictors of the population growth rate of guanacos at this site.

Between 1979 and 1998, [65] conducted a live-trapping study of long-tailed rice rat (Oligoryzomys longicaudatus) at the San Martín Experimental Preserve near Valdivia, Chile $\left(39^{\circ} 38 \mathrm{~S} ; 73^{\circ} 7 \mathrm{~W}\right)$. The authors used modeling approaches to determine how feedback structure, climatic, and stochastic factors influence long-tailed rice rat population dynamics. They observed that populations experienced irregular numerical fluctuations, with first-order feedback structure regulating population change. Firstorder dynamics could be driven by intraspecific competition for food, space, or areas without predators. Population growth rates were influenced by periodic flowering of bamboo (Chusquea spp.) and mast production. Large scale climatic variables - Southern Oscillation and Antarctic Oscillation - had non-linear direct and indirect effects on rice rat population dynamics. Decreased summer rainfall associated with El Niño events $[66,67]$ likely influence seed availability during the next winter, which corresponds with the breeding season of rice rats [65].

Pérez-Alvarez et al. [68] conducted a 14-year study of the Chilean dolphin (Cephalorhynchus eutropia), a species endemic to coastal Chile. Although there are no geographical barriers in its distribution, analysis of microsatellite markers revealed that northern [found in habitat ranging from Valparaíso $\left(33^{\circ} 020 \mathrm{~S}\right)$ to Chiloé $\left(42^{\circ} 000 \mathrm{~S}\right)$ ] and southern populations [(from Chiloé to Navarino Island $\left(55^{\circ} 140 \mathrm{~S}\right)$ ] are genetically distinct. The individuals sampled were located at sites spanning the Chilean coast from $35^{\circ} 20^{\prime} \mathrm{S}$ to $52^{\circ} 40^{\prime} \mathrm{S}$, but despite lacking a physical barrier, there is limited gene flow between the two populations [68]. Potentially, there are ecological or behavioral adaptations to the local habitats that maintain a genetic subdivision of the population.

An impressive number of long-term population monitoring studies on Antarctic seabirds have been sustained, all for 30 or more years ([69-75]; Table 1; Fig. 2). An emerging theme from these studies is that Antarctic seabird populations are sensitive to climate change [71, 76]. Herein, we highlight some of the major insights generated from long-term studies on three penguin species: Magellanic penguins (Spheniscus magellanicus), Adélie penguins (Pygoscelis adeliae), and emperor penguins (Aptenodytes forsteri).

Since 1982, Dee Boersma and colleagues have monitored banded individuals and marked nests in multiple study areas of Magellanic penguins (Spheniscus magellanicus) in Punta Tumbo, Argentina $\left(44^{\circ} 02^{\prime} \mathrm{S}, 65^{\circ} 11^{\prime} \mathrm{W}\right)$. Using a dataset from 1984 to 1991, [16] determined that reproductive success in this population was densitydependent, and that the number of fledglings per active nest decreased with increasing nest density. This finding supports the hypothesis that the value of habitat decreases with increasing density of conspecifics [77]. Likely contributing factors included intraspecific competition and predation, both of which were significantly greater in areas with high nest density than in areas with low nest density. These correlative data were supported by the results of an experimental study showing that fledging success was higher, and that fewer aggressive interactions and less predation occurred in a plot with reduced animal density when compared to control plots [75].

Boersma and colleagues' long-term study has also revealed insights into the impact of climate change on the persistence of colonial bird populations. Using data from 1983 to 2010, [78] determined that starvation and 
predation were the most important predictors of chick mortality across years in Magellanic penguins, although climate variability also negatively influenced reproductive success. The number of storms in early December, when all chicks are less than 30 days of age, increased during the period of this study. Chick mortality due to storms reached 5\% during the period between 2008 and 2010.. The probability of dying increased with increasing rainfall and as the minimum temperature decreased, though these relationships depended on chick age and the interactions between age squared, rainfall and temperature. Climate models predict increasing storm frequency and intensity in the future which would likely lead to increased chick mortality from storms. Chick mortality due to storms occurred disproportionately more from bush nests, which provide lower quality refuges compared with burrow nests. Finally, the synchrony of egg laying has decreased since 1983, increasing the time period that chicks are most vulnerable to storms. Thus, a potential consequence of increased climatic variation is lower recruitment in the years of especially high chick mortality and reduced population persistence.

For over 50 years, researchers have monitored populations of Adélie penguins (Pygoscelis adeliae) of Ross Island colonies $\left(77^{\circ} 34^{\prime} \mathrm{S}, 166^{\circ} 11^{\prime} \mathrm{E}\right)$ and emperor penguins (Aptenodytes forsteri) of Pointe Géologie (Terre Adélie: $66^{\circ} 42^{\prime} \mathrm{S}, 140^{\circ} 15^{\prime} \mathrm{E}$; [2]) and Taylor Glacier colony (67'36' $\left.\mathrm{S}, 62^{\circ} 53^{\prime} \mathrm{E}\right)$ in Antarctica [80]. Adélie penguin populations in the southern Ross Sea have been increasing (0.067 annual growth rate, 2001-2012), though numbers remain lower than they were in early 1980s [81]. In contrast, emperor penguins have been in decline, with a $50 \%$ drop in numbers since the 1970s [71, 82]. Jenouvrier and colleagues have coupled demographic data and modeling techniques to identify factors underlying changes in emperor penguin populations at Terre Adélie. One explanation for the decline in emperor penguins is a warming event that occurred in the southern Indian Ocean during the 1970s and that reduced sea ice extent [71, 82]. A comparison of the Terre Adélie colony with another declining colony at Haswell Island $\left(66^{\circ} 32^{\prime} \mathrm{S}, 93^{\circ}\right.$ $07^{\prime} \mathrm{E}$ ), revealed that numbers of breeding male emperor penguins correlated similarly to sea ice extent in both colonies, suggesting climate fluctuations as a main cause of population changes in the species ([83]; but see [73, 81]). Decreasing sea ice cover seems to be correlated with population declines in both species. However, Ainley et al. [84] suggested two alternative explanations for changes in population density: (i) ocean food web disturbances due to climate fluctuations, and (ii) Antarctic Oscillations, or pressure variance that influences winds and sea ice transport. Adélie penguins are sensitive to size of polynya (open water surrounded by ice) and seasonal growth rates, while emperor penguins seem more sensitive to sea ice extent due to their breeding habits [84]. Regardless, climate fluctuations are likely to be blamed for population declines in both species.

Prado et al. [85] used 38 years of data on marine mammal stranding along the east coast of South America to analyze shifts in distributions and mortality rates in marine mammals. Five species made up $97 \%$ of all strandings: Franciscana dolphins (Pontoporia blainvillei), bottlenose dolphins (Tursiops truncatus), South American fur seals (Arctocephalus australis), subantarctic fur seals (Arctocephalus tropicalis), and South American sea lions (Otaria flavescens). These species are particularly vulnerable to fishing mortality, as some species had higher stranding rates in months correlating with increased fishing, and these coastal habitats may also influence their relatively high stranding rate when to species that live in the deeper ocean. Further marine mammal stranding analysis may highlight the link between oceanic processes and species distribution patterns

Vales et al. [86] examined diets in South American fur seals (Arctocephalus australis) stranded between 1994 and 2011 along the coast of Brazil (from $29^{\circ} 19^{\prime} \mathrm{S}, 49^{\circ} 43^{\prime}$ $\mathrm{W}$ to $31^{\circ} 15^{\prime} \mathrm{S}, 50^{\circ} 54^{\prime} \mathrm{W}$ ). They recorded the consistent reliance by this species on pelagic fish species as a food source over the 17 years of study, noting the corresponding low consumption of demersal and benthic species. Despite an increase of trawling targeting demersal and benthic species in the area since the mid-1990s, the diet of $A$. australis has not been significantly affected. = However, the authors note that overfishing of other species could lead to negative effects on fur seals. Marine mammals may be at risk due to fishing mortality [85], as well as indirect effects caused by fishing such as increased competition for food [86]. These long-term studies will be critical for the monitoring of such effects.

\section{Community ecology}

To date, there have only been a few long-term studies on vertebrate communities in central and South America. However, this limited number of studies has made important contributions to our understanding of the potential effects of abiotic and biotic factors and evolutionary history have on community processes. Herein, we review two long-term studies of small mammal communities in Chile and Argentina.

Since the 1970's, agricultural practices have altered the habitats in the Rolling Pampas region of Argentina $\left(34^{\circ} 08^{\prime} \mathrm{S}, 59^{\circ} 14^{\prime} \mathrm{W}\right)$, where much of the original vegetation and food resources consumed by rodent communities have been replaced with soy and agricultural crops [87]. Live-trapping conducted over 24 years (1984-2008) revealed that the transformation of native habitat to agricultural habitat had dramatic but species-specific 
effects on the native rodents in the community. Interannual fluctuation in the abundance of Azara's grass mouse (Akodon azarae), the dominant competitor in the rodent community, was attributed more strongly to variation in precipitation than changes in the physical habitat [87]. In comparison, the yellow pygmy rice rat (Oligoryzomys flavescens) numbers decreased within the converted agricultural areas, but increased in crop field borders. The numbers of the small vesper mouse ( $\mathrm{Cal}$ omys laucha), a generalist species, increased following changes in habitat [87]. Finally, invasive species including the house mouse (Mus musculus), black rat (Rattus rattus), and Norway rat (Rattus norvegicus) predictably became more abundant during the transformation from native to agricultural habitats $[87,88]$. The observed changes in rodent community composition have been hypothesized to be driven by interspecific competition, in which dominant species such as A. azarae force others out into less suitable habitat (i.e. soy crop fields) through competitive exclusion of resources [88].

Since the late 1970s, Peter Meserve, Fabian Jaksic, Julio Gutiérrez, Douglas Kelt and others [9, 24, 89, 90]) have been studying small mammal community responses to environmental conditions in a thorn scrubland habitat in Parque Nacional Bosque Fray Jorge (PNBFJ), a World BioSphere Reserve in north-central Chile $\left(30^{\circ} 08^{\prime} \mathrm{S}, 59^{\circ} 14^{\prime} \mathrm{N}\right)$. The location is impacted by El Nino-Southern Oscillation (ENSO) events every 5-7 years, allowing Meserve and colleagues to determine how dramatic, periodic fluctuations in rainfall influence both population [91] and community structure [9, 24, 90]. ENSO-related rainfall in western South America leads to a complex set of biotic responses involving bottom-up and top-down processes [89]. Bottom-up regulation involves vegetation and seed blooms, followed by small rodent increases, which lead to predator increases [89, 92-94]. Following an ENSO event between 2000 and 2002, the density of the herbivorous rodent, Octodon degus, increased dramatically [24, 94]. In turn, high degu densities have direct top-down effect on native herbs and indirect effects on invasive annual herbs $[89,94]$. The Meserve et al. study is unique in that the investigators have monitored the response of small mammal communities to experimental manipulations of competitor density (Octodon degus) and predation risk for $>25$ years (1989-present). Not surprisingly, this study has generated $>70$ papers and informed a wide range of community ecology theory (see $[9,24,89]$ for synthetic reviews). Most importantly, the work has supported the hypothesis that community composition is regulated by a complex interaction between abiotic and biotic factors.

An initial aim of the study developed at PNBFJ was to determine how biotic factors, such as predation, regulate the small mammal community through a shifting balance of top-down and bottom-up control [89]. The exclusion of predators and perceived risk of predation influences some aspects of spatial ecology $[95,96]$ and survival of degus [89] and other small mammals in the community $[89,95]$. However, and contrary to theory, predator exclusion did not have a strong effect on the abundances of other small mammals in the community, namely murid rodents and a marsupial species (e.g. [24]). Furthermore, the effect of predators on space use seem smaller compared with thermoregulatory constraints [97], yet its effect on degu abundance is greater during drought years than wet years [74].

The demographic responses of small mammals to periodic fluctuations in rainfall vary depending on life history strategies and residency status $([90,91,98])$. Two multiparous species with short lifespans, short gestations and large litters, Darwin's leaf-eared mouse (Phyllotis darwini) and the olive grass mouse (Abrothrix olivaceus - now A. olivacea) undergo rapid increases in abundance within 3-4 months after periods of high rainfall $[24,90]$. High reproductive output also increases persistence of these species in drought years [90]. In contrast, the abundance of Octodon degus - which has lower reproductive output - increases slowly, with a 1-2 year time lag following peak rainfall [90] and is less resilient in drought years [99]. In terms of residency in the thorn scrub, there are species-specific effects of rainfall on the abundance of two opportunistic rodents found in the thorn scrubland (long-tailed pygmy rice rat, Oligoryzomys longicaudatus, and long-haired grass mouse, Abrothrix longipilis; [100]). O. longicaudatus is characterized as being sporadic and with long periods of absence from the thorn scrubland [76]. In comparison, A. longipilis exhibit much less pronounced periods of increase during wet years [76]. All species used nearby mesic habitats during periods of drought [79].

Since the early 2000s, an increase in rainfall and a decline in the inter-annual variation of rainfall in Meserve and colleagues' study site has resulted in fewer pronounced periods of drought. Consequently, there has been a major shift in small mammal composition. Octodon degus abundance has become more stable and less temporally variable [24] contributing more to small mammal biomass in the thorn shrubland [24, 90, 99]. This change can have critical consequences to the community for multiple reasons. First, degu herbivory and behavior has complex effects on plant diversity including negative impacts on perennial plant diversity through degu herbivory [24]. In contrast, degu runway development and digging is thought to have a positive effect on the density of annual plant seed densities [94, 101]. In this way, the abundance of degus has indirect effects on other small mammals by increasing or decreasing the availability of food and cover (critical for shade, safety). Additionally, degus are superior competitors than most 
of the other small mammals in the community [97]. Based on giving up densities (GUDs), the foraging of some species, such as Abrothrix olivaceus, is less efficient in areas in which degus have access [97]. Taken together, long-term studies at PNBFJ have highlighted how abiotic and biotic ecological conditions interact at different levels and temporal scales to influence demography and space use of small mammals.

Studies lead by Fabian Jaksic, Mauricio Lima, Matias Arim, and Ariel Farias at Las Chinchillas National Reserve, near Auco, Chile $\left(31^{\circ} 30^{\prime} \mathrm{S}, 71^{\circ} 06^{\prime} \mathrm{W}\right)$ focused on vertebrate predator assemblages. Arim et al. [102] studied diets of 6 predatory species [burrowing owl (Speotyto cunicularia), Magellan horned owl (Bubo magellanicus), austral pygmy owl (Glaucidium nanum), barn owl (Tyto alba), American kestrel (Falco sparverius), and culpeo fox (Lycalopex culpaeus) to monitor food chain lengths based on diet composition and trophic position. The authors' scale designated a predator with a diet of only herbivorous prey as having the lowest possible trophic position, while a diet of only nonherbivorous prey would indicate the top most trophic position. They discovered an overall positive association between precipitation and food chain length, which may not have been uncovered on a short-term scale. These studies also have revealed effects linked to long-term fluctuations in climate. Previtali et al. [89] Lima et al. [103] and Farias and Jaksic [29] determined that increased small-mammal abundance, and thus predator food availability, correlated positively with increased rainfall (corresponding with El Nino events). Farias and Jaksic $[105,106]$ compared empirical data with models and identified two divergent predatory species groups in Las Chinchillas National Reserve, one which mostly fed on small mammals, and another with a more varied, generalized diet. Changes in the functional structure of this assemblage can be attributed to the relationship between species composition and abundance of main and alternative prey. The two predatory species groups will vary their diets depending on mammal prey availability having higher niche overlap in extremely favorable or extremely scarce prey resource conditions, and less overlap during moderate prey shortages [106]. Similarly, Farias and Jaksic [104] showed how functional diversity of the predator assemblage in Las Chinchillas National Reserve is influenced by changes in taxonomic composition as well as behavioral responses by the predatory species.

Summary of major insights This selective review of long-term studies in central and South America and Antarctica highlights the advantages of long-term studies over short-term studies. Overall, these advantages are materialized at different scales of analysis or themes:
Social systems: Long-term studies of animal social systems in Central and South America have generated valuable insights into the role of sexual conflict in social monogamous species, and the influence of ecology on the formation and reproductive consequences of social systems. For example, giant otter social organization may be influenced by resource availability, and guanaco and primate mating success is tied to territoriality and social structure. Another major theme that has emerged is that there is contradictory evidence on how ecology influences social systems. On the one hand, short-term studies of $C$. sociabilis and $O$. degus suggest that ecological conditions do not influence the formation of groups. However, a long-term study of $O$. degus has shown that harsh conditions influence the direct fitness consequences of group living [29], suggesting that researchers need to rethink how we examine the effects of ecology on the reproductive consequences of social systems.

Population and evolutionary ecology: Long-term studies of population ecology, largely in Antarctica, have provided valuable census data for modeling the impact of environmental perturbations on populations.

However, in guanacos, population density seems to have the largest influence on survival. Rice rats seem to be affected by vegetation and its response to extreme weather events [107]. Current models project high probabilities of extinction in seabirds due to climatemediated effects on sea ice levels [108]. Other factors, including ENSO effects and snow falls [109], impact seabird colonies in Antarctica, suggesting that weather variation caused by climate change should also be monitored on a long-term scale. The Grants' groundbreaking study of Galapagos finches would not have been observed on a smaller time scale.

Community ecology: Despite a paucity of long-term studies on community ecology, Jaksic and colleagues' work in Las Chinchillas National Reserve and Meserve and colleagues' work in Parque Nacional Bosque Fray Jorge have had major impacts on our understanding of community processes. Jaksic, and Lima have given insight specifically to how ENSO rainfall influences bottom-up community structure ([91]; [92]). Most critically, the work suggests that changes in rainfall patterns, mediated by climate change, can have unexpected consequences at regional and local scales, an idea that is supported by other long-term studies in other arid regions of the world [110, 111]. A major take home message of Meserve and colleagues' long-term 
study is that the previous view that predators and herbivores have predictable and strong impacts on communities is overly simplistic. More likely, biotic interactions are modulated by abiotic conditions, namely the amount and evenness of rainfall [24]. Understanding these dynamics is critical to predicting how other perturbations, such as overgrazing and invasion of exotic species, influence communities.

\section{Challenges and future directions}

Long-term studies involve some important challenges to researchers. Some of these are highlighted by how our ability to place causal inferences about biological processes being monitored may be compromised by lack of continuity in the data sets. For instance, the emperor penguin study at Taylor Glacier includes a 12-year period (1976-1987) during which census data were not collected. Consequently, Robertson and colleagues ([80]) were not able to explain the reason for the observed population decline because they lacked critical demographic data. The lack of a complete dataset in this study highlights the enormous challenges that researchers face in maintaining a long-term study. Long-term studies are daunting, carrying significant professional risks to project leaders. Gaps in data collection, such as those reported in Robertson et al. [80], can occur for a number of reasons, including natural events that prevent access to sites or decimate populations (e.g. volcanic eruptions, storms, droughts, earthquakes). Changes in the local political landscape, land use practices, or access to sites can also prevent work from being accomplished or require changes in location, as two of us (Loren Hayes and Luis Ebensperger) experienced following a permitting decision made by a national park service administration (CONAF-Chile). Inevitably, gaps in funding or institutional support, or changes in personnel also may impact the ability of research teams to keep a long-term study going. For example, funding cycles only last 3-5 years; thus, maintaining a long-term study site involves researchers spending time writing new grants proposing new hypotheses to justify long-term monitoring.

Effective long-term studies generate new questions and change paradigms (see [89]. Consequently, researchers engaged in long-term studies need the resources and logistical support required to change or add to research protocols in ways that do not compromise the consistency and quality long-term datasets. For example, in 2008, Meserve et al. added new experimental plots and began using other plots previously used for food addition experiments (Meserve et al. 2001). The changes were made in part, so that they could monitor the effect of increasingly invasive lagomorphs on vegetation [24]. We now know that the exclusion of lagomorphs resulted in changes in some perennial shrubs [24], which could in turn, influence spatial ecology of small mammals that forage or nest underneath shrubs.

Long-term field studies are powerful because they can track changes to natural systems before and after natural and anthropogenic disturbances. Although there are several long-term studies tracking the effects of natural disturbances such as ENSO on natural systems in Central and South America (e.g., [24, 58, 112]), studies of human effects on birds and mammals are rare [71, 87]. Understanding human impacts on natural systems probably requires the simultaneous monitoring of species in protected areas and human-impacted areas within the same ecosystem. One such study in South America, a > 25 year study of coastal communities in the protected area of Las Cruces, Chile and nearby human-impacted coastline [113], has provided valuable information on how human activity has changed coastal ecosystems. More research like La Cruces study, while logistically challenging and expensive, is needed to inform conservation policy.

\section{Conclusions}

While the risks of long-term studies are high, the benefits to researchers and more importantly, the quality of science that we do, can be substantial [5]. Long-term ecological research in central and South America and Antarctica has uncovered new information that otherwise would not have been recorded and informed behavioral, ecological, evolutionary theory as well as conservation biology. Some studies, such as a long-term study of Phyllostomidae bats in Panama [114], are excellent examples of how long-term studies can integrate levels of analysis. Ultimately, the integration of data from multiple long-term study sites, such as Parque Nacional Bosque Fray Jorge and Parque Nacional Las Chinchillas (both in Chile), may allow a broader understanding of how rainfall influences populations and communities.

This review has revealed a consistent theme, where ecological conditions shape social systems, populations, and communities, but in more complex ways than previously thought. Within a single season or a few seasons, it may not be possible to detect the effects of environmental variation at these levels, as factors such as resource availability and patchiness, rainfall, predation, weather and climate vary year to year and decade to decade as a result of other factors. Long-term research also allows us to assess how different life history and social strategies respond to these environmental changes. Future efforts to build long-term datasets will improve scientific understanding in numerous ways including, increasing the quality of data available for comparative studies, providing necessary data for conservation efforts, and generating baseline data from which future changes can be measured. Thus, we hope that this review motivates interest and investment in future long-term studies in the region. 


\section{Abbreviations}

ENSO: El Niño-Southern Oscillation; GUD: Giving-up density; LTER: Long-term ecological research; PNBFJ: Parque Nacional Bosque Fray Jorge

\section{Acknowledgements}

We thank Fabian Jaksic for a critical review of the manuscript.

\section{Funding}

This project was funded by NSF OISE grant no. 1261026 to LDH and FONDECYT 1130091 to LAE.

\section{Availability of data and materials}

Not applicable

\section{Authors' contributions}

MTJ contributed to writing of the social ecology section as well as edits to other sections. MKS contributed to the writing of the community ecology section and made the figures. KC contributed to the writing of the evolutionary and population ecology section. KN edited all sections, formatted the manuscript, and contributed citations. LE contributed to writing of the manuscript as well as edits of drafts. LDH conceived of the review topic and contributed to the writing of the manuscript. All authors read and approved of the final manuscript.

\section{Ethics approval and consent to participate}

Not applicable

\section{Consent for publication}

Not applicable

\section{Competing interests}

The authors declare that they have no competing interests.

\section{Publisher's Note}

Springer Nature remains neutral with regard to jurisdictional claims in published maps and institutional affiliations.

\section{Author details \\ 'Department of Biology, Geology, and Environmental Science, University of Tennessee at Chattanooga, 615 McCallie Ave, Chattanooga, TN 37405, USA. ${ }^{2}$ Department of Environmental Science, Policy and Management, University of California, 110 Sproul Hall, Berkeley, CA 94720, USA. ${ }^{3}$ Department of Biology, Tufts University, 419 Boston Ave, Medford, MA 02155, USA. ${ }^{4}$ Facultad de Ciencias Biológicas, P. Universidad Católica de Chile, Avda. Libertador Bernardo O'Higgins, 340 Santiago, Chile.}

Received: 10 January 2017 Accepted: 10 August 2017 Published online: 06 September 2017

\section{References}

1. Anderson CB, Celis-Diez JL, Bond BJ, Martinez PG, Little C, Armesto JJ, Carmona M. Progress in creating a joint research agenda that allows networked long-term socio-ecological research in southern South America: addressing crucial technological and human capacity gaps limiting its application in Chile and Argentina. Austral Ecology. 2012;37(5):529-36.

2. Clutton-Brock T, Sheldon BC. Individuals and populations: the role of longterm, individual-based studies of animals in ecology and evolutionary biology. Trends Ecol Evol. 2010;25(10):562-73.

3. Hayes LD, Schradin C. Long-term field studies of mammals: what the shortterm study cannot tell us. J Mammal. 2017;98:600-2.

4. Lindenmayer DB, Likens GE, Andersen A, Bowman D, Bull CM, Burns E, Lowe AJ. Value of long-term ecological studies. Austral Ecol. 2012;37(7):745-57.

5. Schradin C, Hayes LD. A synopsis of long-term field studies of mammals: achievements, future directions, and some advice. J Mammal. 2017:98:670-7.

6. Vanderbilt K, Gaiser E. The international long term ecological research network: a platform for collaboration. Ecosphere. 2017:8(2):e01697.

7. Maldonado-Chaparro AA, Martin JG, Armitage KB, Oli MK, Blumstein DT. Environmentally induced phenotypic variation in wild yellow-bellied marmots. J Mammal. 2015;96(2):269-78.
8. Martínez-Padilla J, Redpath SM, Zeineddine M, Mougeot F. Insights into population ecology from long-term studies of red grouse Lagopus Lagopus Scoticus. J Anim Ecol. 2014;83(1):85-98.

9. Gutierrez JR, Meserve PL, Kelt DA, Engilis A Jr, Andrea M. Long-term research in Bosque fray Jorge National Park: twenty years studying the role of biotic and abiotic factors in a Chilean semiarid scrubland. Rev Chil Hist Nat. 2010;83(1):69-98.

10. Rees M, Condit R, Crawley M, Pacala S, Tilman D. Long-term studies of vegetation dynamics. Science. 2001;293(5530):650-5.

11. Sinclair ARE, Mduma S, Brashares JS. Patterns of predation in a diverse predator-prey system. Nature. 2003;425(6955):288-90.

12. Brown JH, Whitham TG, Ernest SM, Gehring CA. Complex species interactions and the dynamics of ecological systems: long-term experiments. Science. 2001;293(5530):643-50.

13. Grimm NB, Grove JG, Pickett ST, Redman CL. Integrated approaches to longterm studies of urban ecological systems urban ecological systems present multiple challenges to ecologists - pervasive human impact and extreme heterogeneity of cities, and the need to integrate social and ecological approaches, concepts, and theory. Bioscience. 2000;50(7):571-84.

14. Hughes TP, Connell JH. Multiple stressors on coral reefs: a long-term perspective. Limnol Oceanogr. 1999:44(3):932-40.

15. Lindenmayer DB, Likens GE. Adaptive monitoring: a new paradigm for longterm research and monitoring. Trends Ecol Evol. 2009;24(9):482-6.

16. Turner MG, Collins SL, Lugo AL, Magnuson JJ, Rupp TS, Swanson FJ. Disturbance dynamics and ecological response: the contribution of longterm ecological research. Bioscience. 2003;53(1):46-56.

17. Willis KF, Bailey RM, Bhagwat SA, Birks HJB. Biodiversity baselines, thresholds and resilience: testing predictions and assumptions using palaeoecological data. Trends Ecol Evol. 2010;25(10):583-91.

18. Holmgren M, Stapp P, Dickman CR, Gracia C, Graham S, Gutierrez JR, Hice C, Jaksic F, Kelt DA, Letnic M, Lima M, Lopez BC, Meserve PL, Milstead WB, Polis GA, Previtali MA, Richter M, Sabate S, Squeo FA. Extreme climatic events shape arid and semiarid ecosystems. Front Ecol Environ. 2006;4(2): 87-95.

19. Petelle MB, Martin JGA, Blumstein DT. Heritability and genetic correlations of personality traits in a wild population of yellow-bellied marmots (Marmota Flaviventris). J Evol Biol. 2015;28(10):1840-8.

20. Willis KJ, Araújo MB, Bennett KD, Fiqueroa-Rangel B, Froyd CA, Myers N. How can a knowledge of the past help to conserve the future? Biodiversity conservation and the relevance of long-term ecological studies. Philosophical Trans Royal Soc B. 2007;362(1478):175-87.

21. Koenig WD, Dickinson JL. Cooperative breeding in vertebrates: studies of ecology, evolution, and behavior: Cambridge University Press; 2016.

22. Grant PR, Grant BR. Unpredictable evolution in a 30-year study of Darwin's finches. Science. 2002;296(5568):707-11.

23. Grant PR, Grant BR. 40 Years of evolution: Darwin's finches on Daphne Major Island. Princeton (New Jersey): Princeton University Press; 2014. p. 400.

24. Meserve PL, Kelt DA, Gutierrez JR, Previtali MA, Milstead WB. Biotic interactions and community dynamics in the semiarid thorn scrub of Bosque fray Jorge National Park, north-central Chile: a paradigm revisited. J Arid Environ. 2016;126:81-8.

25. Carmona MR, Aravena JC, Bustamante-Sanchez MA, Celis-Diez JL, Charrier A, Díaz IA, Díaz-Forestier J, Diaz MF, Gaxiola A, Gutiérrez AG, Hernandez-Pellicer C. Senda Darwin Biological Station: long-term ecological research at the interface between science and society. Rev Chil Hist Nat. 2010;83(1):113-42.

26. Rozzi R, Armesto JJ, Gutiérrez JR, Massardo F, Likens GE, Anderson CB, Poole A, Moses KP, Hargrove E, Mansilla AO, Kennedy JH. Integrating ecology and environmental ethics: earth stewardship in the southern end of the Americas. Bioscience. 2012:62(3):226-36.

27. Anderson CB, Rozzi R, Armesto JJ, Gutiérrez JR. Building a Chilean network for long-term socio-ecological research: advances, perspectives and relevance. Rev Chil Hist Nat. 2010:83:1-12.

28. Rozzi R, Anderson CB, Pizarro JC, Massardo F, Medina Y, Mansilla AO, Moses K. Field environmental philosophy and biocultural conservation at the Omora Ethnobotanical Park: methodological approaches to broaden the ways of integrating the social component (" S") in long-term socioecological research (LTSER) sites [material Complementario]. Rev Chil Hist Nat. 2010;83

29. Ebensperger LA, Villegas Á, Abades S, Hayes LD. Mean ecological conditions modulate the effects of group living and communal rearing on offspring production and survival. Behav Ecol. 2014:aru061. 
30. Lacey EA. Sociality reduces individual direct fitness in a communally breeding rodent, the colonial tuco-tuco (Ctenomys Sociabilis). Behav Ecol Sociobiol. 2004;56(5):449-57.

31. Fernandez-Duque E, Huck M. Till death (or an intruder) do us part: Intrasexual-competition in a monogamous primate. PLoS One. 2013;8(1): e53724. doi: 10.1371/journal.pone.0053724.

32. Porter AM, Grote MN, Isbell LA, Fernandez-Duque E, Di Fiore A. A Saki Saga: dynamic and disruptive relationships among Pithecia Aequatorialis in Ecuador. Folia Primatol. 2015:86(5):455-73.

33. Schwindt DM, Carrillo GA, Braco JJ, Di Fiore A, Fernandez-Duque E. Comparative socioecology of monogamous primates in the Amazon and Gran Chaco. Int J Primatol. 2004;75:412.

34. Van Belle S, Fernandez-Duque E, Di Fiore A. Demography and life history of free-ranging red titi monkeys (Callicebus Discolor) and equatorial sakis (Pithecia Aequatorialis) in Amazonian Ecuador: a 12-year study. Am J Primatol. 2016;78:204-15.

35. Groenendijk J, Hajek F, Johnson PJ, Macdonald DW, Calvimontes J, Staib E, Schenck C. Demography of the Giant otter (Pteronura Brasiliensis) in Manu National Park, south-eastern Peru: implications for conservation. PLoS One. 2014;9(8):e106202. doi: 10.1371/journal.pone.0106202.

36. Groenendijk J, Hajek F, Schenck C, Staib E, Johnson PJ, MacDonald DW. Effects of territory size on the reproductive success and social system of the giant otter, south-eastern Peru. J Zool. 2015;296(3):153-60.

37. Marino J, Sillero-Zubiri C, Johnson PJ, Macdonald DW. Ecological bases of philopatry and cooperation in Ethiopian wolves. Behav Ecol Sociobiol. 2012; 66(7):1005-15.

38. Ortega I, Franklin WL. Social organization, distribution, and movements of a migratory guanaco population in the Chilean Patagonia. Rev Chil Hist Nat. 1995;68:489-500

39. Franklin WL. Contrasting social ecologies of south American camelids: the vicuna and guanaco. In: Eisenberg JF, Kleiman D, editors. Advances in the study of mammalian behavior: American Society of Mammalogy; 1983. p. 573-629. Special Publications No. 7.

40. Young JK, Franklin WL. Territorial fidelity of male guanacos in the Patagonia of southern Chile. J Mammal. 2004;85(1):72-8.

41. Edge WD, Marcum CL. Movements of elk in relation to logging disturbance. J Wildl Manag. 1985;49:926-30.

42. Edge WD, Marcum CL, Olsen SL. Effects of logging on home-range fidelity of elk. J Wildl Manag. 1985;49:741-4.

43. Jurgensen TE. Seasonal territoriality in a migratory guanaco population. Ames: M.S. thesis, lowa State University; 1985.

44. Veiga JP, Moreno J, Cordero PJ, Mínguez E. Territory size and polygyny in the spotless starling: resource-holding potential or social inertia? Can J Zool. 2001;79(11):1951-6.

45. Lacey EA, Braude SH, Wieczorek JR. Burrow sharing by colonial tuco-tucos (Ctenmys sociabilis). J Mammal. 1997;78(2):556-62.

46. Lacey EA, Wieczorek JR. Kinship in colonial tuco-tucos: evidence from group composition and population structure. Behav Ecol. 2004;15(6):988-96.

47. Jarvis JUM, O'Riain MJ, Bennett NC, Sherman PW. Mammalian eusociality: a family affair. Trends Ecol Evol. 1994;9(2):47-51.

48. Lacey EA, Wieczorek JR. Ecology of sociality in rodents: a ctenomyid perspective. J Mammal. 2003;84(4):1198-211.

49. Tammone MN, Lacey EA, Relva MA. Habitat use by colonial tuco-tucos (Ctenomys sociabilis): specialization, variation, and sociality. J Mammal. 2012; 93(6):1409-19.

50. Izquierdo G, Lacey EA. Effects of group size on nest attendance in the communally breeding colonial tuco-tuco. Mamm Biol. 2007;73:438-43.

51. Ebensperger LA, Ramirez-Estrada J, Leon C, Castro RA, Tolhuysen LO, Sobrero R, Quirici V, Burger JR, Soto-Gamboa M, Hayes LD. Sociality, glucocorticoids and direct fitness in the communally rearing rodent, Octodon degus. Horm Behav. 2011;60:346-52.

52. Ebensperger LA, Chesh AS, Castro RA, Tolhuysen LO, Quirici V, Burger JR, Hayes LD. Instability rules social groups in the communal breeder rodent Octodon degus. Ethology. 2009;115:540-54.

53. Davis GT, Vásquez RA, Poulin E, Oda E, Bazán-León EA, Ebensperger LA. Hayes LD Octodon Degus kin and social structure. J Mammal. 2016;97(2):361-72.

54. Quirici V, Faugeron S, Hayes LD, Ebensperger LA. The influence of group size on natal dispersal in the communally rearing and semifossorial rodent, Octodon Degus. Behav Ecol Sociobiol. 2011;65(4):787-98.

55. Hayes LD, Chesh AS, Castro RA, Tolhuysen LO, Burger JR, Bhattacharjee J, Ebensperger $L A$. Fitness consequences of group living in the degu Octodon
Degus, a plural breeder rodent with communal care. Anim Behav. 2009; 78(1):131-9.

56. Ebensperger LA, Tapia D, Ramirez-Estrada J, Leon C, Soto-Gamboa M, Hayes LD. Fecal cortisol levels predict breeding but not survival of females in the short-lived rodent, Octodon Degus. Gen Comp Endocrinol. 2013;186:164-71.

57. Ebensperger LA, Correa L, León C, Ramírez-Estrada Abades S, Villegas A, Hayes LD. The modulating role of group stability on fitness effects of group size is different in females and males of a communally rearing rodent. J Anim Ecol. 2016;85:1502-15.

58. Grant BR, Grant PR. Evolution of Darwin's finches caused by a rare climatic event. Proc R Soc Lond B Biol Sci. 1993;251(1331):111-7.

59. Sarno RJ, Franklin WL. Population density and annual variation in birth mass of guanacos in southern Chile. J Mammal. 1999;80(40):1158-62.

60. Robinson JJ. The influence of maternal nutrition in ovine fetal growth. Proc Nutr Soc. 1977:36:9-16.

61. Willis MB, Wilson A. Factors affecting birth weight of Santa Gertrudis calves. Anim Prod. 1974:18:231-6.

62. Gustafson LL. Predicting early mortality of newborn guanacos by birth mass and hematological parameters: a provisional model. J Wildl Manag. 1998;62: 24-35.

63. Sarno RJ, Clark WR, Bank MS, Prexl WS, Behl MJ, Johnson WE, Franklin WL. Juvenile guanaco survival: management and conservation implications. J Appl Ecol. 1999;36(6):937-45.

64. Zubillaga M, Skewes O, Soto N, Rabinovich JE. Density but not climate affects the population growth rate of guanacos (Lama Guanicoe) (Artiodactyla, Camelidae). Food Res. 2014;2(210):F1000Research 2.

65. Murua R, Gonzalez LA, Lima M. Population dynamics of rice rats (a hantavirus reservoir) in southern Chile: feedback structure and non-linear effects of climatic oscillations. Oikos. 2003;102:137-45.

66. Montecinos A, Aceituno P. Seasonality of the ENSO related rainfall variability in central Chile and associated circulation anomalies. J Clim. 2003;16:281-96.

67. Montecinos A, Diaz A, Aceituno PJC. Seasonal diagnostic and predictability of rainfall in subtropical South America based on tropical pacific SST. J Clim. 2000;13:746-58.

68. Pérez-Alvarez MJ, Olavarría C, Moraga R, Baker CS, Hamner RM, Poulin E. Microsatellite markers reveal strong genetic structure in the endemic Chilean dolphin. PLoS One. 2015;10(4):e0123956. doi: 10.1371/journal.pone.0123956.

69. Carneiro AP, Manica A, Phillips RA. Long-term changes in population size, distribution and productivity of skuas (Stercorarius spp.) at Signy Island, south Orkney Islands. Polar Biol. 2016;39(4):617-25.

70. Dunn MJ, Jackson JA, Adlard S, Phillips RA. Population size and trends of southern giant petrels (Macronectes Giganteus) nesting at Signy Island, south Orkney Islands. Polar Biol. 2015:1-9.

71. Jenouvrier S, Weimerskirch H, Barbraud C, Young-Huang P, Cazelles B. Evidence of a shift in the cyclicity of Antarctic seabird dynamics linked to climate. Proc R Soc B. 2005;272:887-95.

72. Krietsch J, Esefeld J, Braun C, Lisovski S, Peter HU. Long-term dataset reveals declines in breeding success and high fluctuations in the number of breeding pairs in two skua species breeding on king George Island. Polar Biol. 2016;39(4):573-82.

73. LaRue MA, Kooyman G, Lynch HJ, Fretwell P. Emigration in emperor penguins: implications for interpretation of long-term studies. Ecography. 2014:37:001-7.

74. Micol T, Jouventin P. Long-term population trends in seven Antarctic seabirds at Pointe Géologie (Terre Adélie) human impact compared with environmental change. Polar Biol. 2001;24(3):175-85.

75. Stokes DL, Boersma PD. Nesting density and reproductive success in a colonial seabird, the Magellanic penguin. Ecology. 2000;81(10):2878-91.

76. Croxall JP, Trathan PN, Murphy EJ. Environmental change and Antarctic seabird populations. Science. 2002;297(5586):1510-4.

77. Rosenzweig ML. Habitat selection and population interactions: the search for mechanism. Am Nat. 1991:137:S5-S28.

78. Boersma PD, Rebstock GA. Climate change increases reproductive failure in magellanic penguins. PLoS One. 2014;9(1):85602. doi: 10.1371/ journal.pone. 0085602.

79. Ainley D, Russell J, Jenouvrier S, Woehler E, Lyver POB, Fraser WR, Kooyman $\mathrm{GL}$. Antarctic penguin response to habitat change as Earth's troposphere reaches 2 C above preindustrial levels. Ecol Monogr. 2010;80(1):49-66.

80. Robertson G, Wienecke B, Emmerson L, Fraser AD. Long-term trends in the population size and breeding success of emperor penguins at the Taylor glacier colony Antarctica. Polar Biol. 2014;37:251-9. 
81. Lyver POB, Barron M, Barton KJ, Ainley DG, Pollard A, Gordon S, Wilson PR. Trends in the breeding population of Adélie penguins in the Ross Sea, 1981-2012: a coincidence of climate and resource extraction effects. PLoS One. 2014;9(3):e91188.

82. Barbraud C, Weimerskirch $\mathrm{H}$. Emperor penguins and climate change. Nature. 2001:411(6834):183-6.

83. Barbraud C, Gavrilo M, Mizin Y, Weimerskirch H. Comparison of emperor penguin declines between Pointe Geologie and Haswell Island over the past 50 years. Antarct Sci. 2011;23(5):461-8.

84. Ainley DG, Clarke ED, Arrigo K, Fraser WR, Kato A, Barton KJ, Wilson PR. Decadal-scale changes in the climate and biota of the Pacific sector of the Southern Ocean, 1950s to the 1990s. Antarct Sci. 2005;17(02):171-82.

85. Prado JH, Mattos PH, Silva KG, Secchi ER. Long-term seasonal and interannual patterns of marine mammal strandings in subtropical western South Atlantic. PLoS One. 2016:11(1):e0146339.

86. Vales DG, Saporiti F, Cardona L, De Oliveira LR, Dos Santos RA, Secchi ER, et al. Intensive fishing has not forced dietary change in the south American fur seal Arctophoca (= Arctocephalus) australis off Río de la Plata and adjoining areas. Aquat Conserv Mar Freshwat Ecosyst. 2014;24(6):745-59.

87. Fraschina J, Leon VA, Busch M. Long-term variations in rodent abundance in a rural landscape of the pampas Argentina. Ecol Res. 2012;27:191-202.

88. Bilenca DN, Kravetz FO. Seasonal variations in microhabitat use and feeding habits of the pampas mouse Akodon Azarae in agroecosystems of central Argentina. Acta Theriol. 1998;43:193-205.

89. Meserve PL, Kelt DA, Milstead WB, Gutiérrez JR. Thirteen years of shifting topdown and bottom-up control. Bioscience. 2003;53(7):633-46.

90. Meserve PL, Kelt DA, Previtali MA, Milstead WB, Gutierrez JR. Global climate change and small mammal populations in north-central Chie. J Mammal. 2011;92(6):1223-35.

91. Previtali MA, Lima M, Meserve PL, Kelt DA, Gutierrez JR. Population dynamics of two sympatric rodents in a variable environment: rainfall, resource availability, and predation. Ecology. 2009;90(7):2009.

92. Jaksic FM. Ecological effects of el Niño in terrestrial ecosystems of western South America. Ecography. 2001;24(3):241-50

93. Lima M, Marquet PA, Jaksic FM. El Niño events, precipitation patterns, and rodent outbreaks are statistically associated in semiarid Chile. Ecography. 1999;22(2):213-8.

94. Madrigal J, Kelt DA, Meserve PL, Gutierrez JR, Squeo FA. Bottom-up control of consumers leads to top-down indirect facilitation of invasive annual herbs in semiarid coastal Chile. Ecology. 2011;92:282-8.

95. Kelt DA, Meserve PL, Karina Nabors L, Forister ML, Gutiérrez JR. Foraging ecology of small mammals in semiarid Chile: the interplay of biotic and abiotic effects. Ecology. 2004;85(2):383-97.

96. Lagos VO, Contreras LC, Meserve PL, Gutiérrez JR, Jaksic FM. Effects of predation risk on space use by small mammals: a field experiment with a Neotropical rodent. Oikos. 1995:259-64.

97. Yunger JA, Meserve PL, Gutierrez JR. Small-mammal foraging behavior: mechanisms for coexistence and implication for population dynamics. Ecol Monogr. 2002;72(4):561-77.

98. Meserve PL, Yunger JA, Gutiérrez JR, Contreras LC, Milstead WB, Lang BK, Cramer KL, Herrera S, Lagos VO, Silva SI, Tabilo EL, Torrealba M, Jaksic FM. Heterogeneous responses of small mammals to an el Nino southern oscillation event in northcentral semiarid Chile and the importance of ecological scale. J Mammal. 1995;76(2):580-95

99. Previtali MA, Meserve PL, Kelt DA, Milstead WB, Gutierrez JR. Effects of more frequent and prolonged el Niño events on life-history parameters of the Degu, a long-lived and slow-reproducing rodent. Conserv Biol. 2010;24(1): 18-28.

100. Milstead WB, Meserve PL, Campanella A, Previtali MA, Kelt DA, Gutiérrez JR Spatial ecology of small mammals in north-central Chile: role of precipitation and refuges. J Mammal. 2007;88(6):1532-8.

101. Gutiérrez JR, Meserve PL, Herrera S, Contreras LC, Jaksic FM. Effects of small mammals and vertebrate predators on vegetation in the Chilean semiarid zone. Oecologia. 1997;109(3):398-406.

102. Arim M, Marquet PA, Jaksic FM. On the relationship between productivity and food chain length at different ecological levels. Am Nat. 2007;169(1):62-72.

103. Lima M, Stenseth NC, Jaksic FM. Food web structure and climate effects on the dynamics of small mammals and owls in semiarid Chile. Ecol Lett. 2002; 5:273-84.
104. Farias AA, Jaksic FM. Hierarchical determinants of the functional richness, evenness and divergence of a vertebrate predator assemblage. Oikos. 2009; 118(4):591-603.

105. Farias AA, Jaksic FM. Effects of functional constraints and opportunism on the functional structure of a vertebrate predator assemblage. J Anim Ecol. 2007a;76(2):246-57.

106. Farias AA, Jaksic FM. El Niño events, the lean versus fat scenario, and longterm guild dynamics of vertebrate predators in a south American semiarid ecosystem. Austral Ecology. 2007b;32:225-38.

107. Jaksic FM, Lima M. 2003. Myths and facts on ratadas: bamboo blooms, rainfall peaks and rodent outbreaks in South America. Austral Ecol. 2003; 28(3):237-51.

108. Grinsted A, Moore JC, Jevrejeva S. Reconstructing sea level from paleo and projected temperatures 200 to 2100 AD. Clim Dyn. 2010;34(4):461-72.

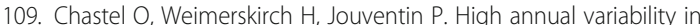
reproductive success and survival of an Antarctic seabird, the snow petrel Pagodroma Nivea. Oecologia. 1993;94(2):278-85.

110. Brown JH, Valone TJ, Curtin CG. Reorganization of an arid ecosystem in response to recent climate change. Proc Natl Acad Sci. 1997;94(18):9729-33.

111. Dickman CR, Greenville AC, Tamayo B, Wardle GM. Spatial dynamics of small mammals in central Australian desert habitats: the role of drought refugia. J Mammal. 2011:92(6):1193-209.

112. Jaksic FM, Silva SI, Meserve PL, Gutiérrez JR. A long-term study of vertebrate predator responses to an el Nino (ENSO) disturbance in western South America. Oikos. 1997:341-54.

113. Navarrete SA, Gelcich S, Castilla JC. Long-term monitoring of coastal ecosystems at Las Cruces, Chile: defining baselines to build ecological literacy in a world of change. Rev Chil Hist Nat. 2010;83:143-57.

114. Giannini NP, Kalko EK. Trophic structure in a large assemblage of Phyllostomid bats in Panama. Nordic Society Oikos. 2004;105(2):209-20.

115. Lima M, Jaksic M. Delayed density-dependent and rainfall effects on reproductive parameters of an irruptive rodent in semiarid Chile. Acta Theriol. 1998;43(3):225-34.

\section{Submit your next manuscript to BioMed Central and we will help you at every step:}

- We accept pre-submission inquiries

- Our selector tool helps you to find the most relevant journal

- We provide round the clock customer support

- Convenient online submission

- Thorough peer review

- Inclusion in PubMed and all major indexing services

- Maximum visibility for your research

Submit your manuscript at www.biomedcentral.com/submit
C) Biomed Central 